\author{
Emilija D. Milojević* \\ Univerzitet u Beogradu \\ Filološki fakultet \\ Katedra za opštu lingvistiku
}

\title{
EJDŽIZAM U DISKURSU O STARIMA ZA VREME PANDEMIJE KORONA VIRUSA U SRBIJI**
}

\author{
Originalni naučni rad \\ UDC 616-036.21:578.834]:316.647.82-053.88/.9 (497.11) \\ $81^{\prime} 42$ \\ https://doi.org/10.18485/kkonline.2021.12.12.8
}

\begin{abstract}
U fokusu ovog rada je analiza diskursa o starima za vreme pandemije korona virusa u Srbiji, sa ciljem da se utvrdi kako se koncept starenja diskurzivno konstruiše, odnosno koji su to dominantni ejdžizmi u našem društvu. Najpre je napravljen korpus koji sadži komentare građana na portalima ispod vesti o korona virusu i izjava državnog vrha na konferencijama za medije povodom aktuelne epidemiološke situacije. Komentari građana na portalima interpretirani su i analizirani kao stav društva prema starima, uz izuzetak malog broja komentara čiji su se autori predstavili kao penzioneri, pa su ti komentari analizirani kao stav starijih sugrađana o pandemiji i merama za suzbijanje virusa. Izjave državnog vrha u vidu vesti na portalima analizirane su kao stav države o najstarijima. $U$ radu je poseban fokus stavljen na koncept ejdžizma, a primeri takvog diskriminatornog jezika identifikovani su u ovom korpusu. Stari se u diskursu države i društva najčešće predstavljaju kao nerazumni, nesposobni da sami donose odluke, neposlušni, nesposobni da upravljaju svojim novcem, dokoni, besposleni i sebični, rasipnici; guraju se po gradskom prevozu i prodavnicama, žele da žive beskonačno, dok društvo smatra da nije strašno ako umiru, jer su se ionako naživeli. Negovanjem diskriminatornog diskursa prepunog ejdžizama normalizuju se i diskriminatorne prakse, te se ovakav diskurs mora preispitivati i odbacivati, umesto prihvatati kao prirodan odnos društva prema starima.
\end{abstract}

Ključne reči: kritička analiza diskursa, ejdžizam, diskriminacija, stari, korpus, diskriminatorne prakse, diskriminatorni diskurs, pandemija korona virusa

\section{Uvod}

Pandemija korona virusa koja je zahvatila svet tokom 2020. godine, osim zdravstvenih, finansijskih i psihičkih problema izazvanih virusom i strahom, donela je i novo plodno tle za pojačanu diskriminaciju prethodno već diskriminisanih, osetljivih društvenih grupa. Pandemija je samo pogoršala već lošu poziciju društveno marginalizovanih grupa i iznela na videlo probleme sa kojima se celokupno društvo, ali najpre upravo osetljive društvene grupe, suočavaju, kao što su male plate i penzije, loše zdravstveno i socijalno osiguranje, neizvesna budućnost.

\footnotetext{
*e-mail: emilijaffbg@gmail.com

** Prvobitna verzija ovog rada nastala je u okviru predmeta Kritička analiza diskursa na master akademskim studijama na Filološkom fakultetu Univerziteta u Beogradu.
} 
Pošto su najstariji građani na početku pandemije predstavljeni kao najugroženiji, upravo su oni trpeli i najstrože mere u borbi sa virusom - bili su zaključavani u svoje domove, najpre bez mogućnosti šetnje, a zatim sa minimalnim vremenom za šetnju; dodeljeni su im neprimereni, noćni sati za kupovinu namirnica, tj. poniženi su i diskriminisani. Ovakve diskriminatorne prakse prema najstarijim građanima u dominantnom diskursu državnog vrha predstavljene su kao zaštita i ljubav prema „bakama i dekama”, što već na početku ovog rada sugeriše koliko jezik ponekad može da izobliči stvarnost. Još ako je takav jezik deo dominantnog diskursa, onda ga i većina prihvata, ne pitajući se kakva je zapravo veza između takvog diskursa i stvarnosti, kako su stariji predstavljeni u dominantnom diskursu i kakve se diskriminatorne prakse kriju iza prividne brige i ljubavi prema penzionerima.

Sva ova pitanja biće u fokusu ovog rada čiji je cilj da ukaže na diskriminatorni diskurs prema najstarijim sugrađanima i njegovu normalizaciju, na opasnosti normalizacije jednog takvog diskursa usled mogućeg opravdavanja diskriminatornih praksi koje iz njega proističu. Cilj je uvideti kojim se jezičkim sredstvima ispoljava ejdžizam u diskursu i objasniti ovakvu društvenu konstrukciju koncepta starenja i stereotipe o starim ljudima iz ugla kritičke analize diskursa.

\section{Diskriminacija zasnovana na životnom dobu ili ejdžizam}

Baveći se jezikom ejdžizma, Džendron i Velford (2016) ukazuju na to da celokupno svetsko stanovništvo stari, imajući u vidu demografske trendove, i da će ubrzo biti više starih ljudi u svetu nego što ih je ikada pre bilo, a tek smo na početku tog trenda. Takođe je verovatno da stariji nikada ranije u tolikoj meri nisu bili diskriminisani i bačeni na marginu društva. Negativnih stavova i stereotipa o starim Ijudima sve je više, a oni su oličeni u diskursu - implicitnom ili eksplicitnom upotrebom diskriminatornog jezika, novih multimedijalnih tvorevina - popularnih mimova, ili se pak prepoznaju u diskriminatornim praksama - izopštavanjem, ponižavanjem i ograničavanjem prava najstarijih.

Ejdžizam, odnosno diskriminacija zasnovana na životnom dobu, može biti teže prepoznatljiva, jer se prihvata kao normalna. Zapravo, mnogi načini ispoljavanja ejdžizma mogu se lako prevideti upravo jer su takvi oblici diskriminacije vrlo suptilni i već ukorenjeni u društvu, pa se kao takvi ni ne prepoznaju kao oblici ponašanja i razmišljanja zasnovani na stereotipima i predrasudama o jednoj starosnoj grupi, već kao normalan odnos između različitih starosnih grupa koje jedna o drugoj ne misle ništa dobro. Takva normalizacija diskriminacije i takvi obrasci predrasuda i stereotipa 
jesu zabrinjavajući, jer se veoma lako usvajaju, neguju i šire, bez preispitivanja toga šta se usvaja kao normalan odnos društva prema jednoj društvenoj kategoriji. Diskriminacija i predrasude na jezičkom planu mogu biti iskazane uvredljivim vokabularom, i zapravo postoji tendencija da se ejdžizam svodi samo na pogrdne načine imenovanja (Bytheway, 1995). Ipak, uvredljivi vokabular nije jedini način reprodukcije diskurzivne i društvene moći: "dominacija može biti iskazana i reprodukovana suptilnim, rutinskim i uobičajenim oblicima teksta i govora koji deluju prirodno i sasvim prihvatljivo" (Van Dijk, 1993:254). Uobičajeni manje ili više suptilni oblici dominacije čine se prirodnim sve dok ne počnu da budu preispitivani - to je slučaj sa dominacijom muškaraca nad ženama, belaca nad crncima, bogatih nad siromašnima, koji se a priori uzimaju kao prirodni raspored moći u društvu (ibid., 255).

Diskriminacija predstavlja primenu verovanja koja se zasnivaju na predrasudama i stereotipima (Fiske, 2010), a jezik i diskriminacija su neraskidivo povezani. Osim činjenice da jezik "kodira diskriminatorne stereotipe i narative koji su povezani sa nejednakošću" ( $\mathrm{Ng}, 2007: 109)$, on takođe doprinosi normalizaciji diskriminacije u svakodnevnom životu. Stoga se može zaključiti da se ni diskriminacija ne može potpuno razumeti bez izučavanja jezika koji igra glavnu ulogu u njenom opstanku i usvajanju, kao i da je verovatno da tamo gde postoji diskriminatorni jezik, postoje i određene diskriminatorne prakse. Ako je većinski diskurs društva prema starima takav da stare ljude označava kao nesposobnu i suvišnu društvenu kategoriju, onda takav diskurs pravi plodno tle za diskriminatorne prakse prema ovoj kategoriji stanovništva. Kada su usmerene ka starim ljudima ili kada opisuju starenje, "određene reči i fraze, iako zamišljene kao benigne ili čak pozitivne, mogu nehotice da prodube negativne stavove, stereotipe, sudove i pretpostavke" (Gendron \& Welleford, 2016:1004).

Grinberg, Šimel i Martens (2002) ejdžizam definišu kao negativan stav ili ponašanje prema nekoj osobi čiji je uzrok samo uzrast te osobe. $U$ tom slučaju, ejdžizam bi označavao i stereotipe i predrasude prema mladima samo zato što su mladi, ili predrasude prema ljudima srednjih godina samo zato što su u tom životnom dobu. Ejdžizmi usmereni ka mladima su takođe česti, ali oni, osim negativnih (mladi su neodgovorni, nezreli, nesamostalni, ne poštuju starije, samo izlaze i provode se, žive na "maminoj i tatinoj grbači” i sl.), mogu biti i pozitivni (mladi su lepi, dobrog zdravlja, uspešni, nemaju nikakvih teškoća i problema, sve mogu jer su mladi), dok su ejdžizmi usmereni ka starijima većinom negativni. Kao što su najčešće konotacije prideva star negativne, tj. označavanje starije životne dobi najčešće konotira 
nedostatak životne snage, nesamostalnost i zavisnost od pomoći drugih; isto tako se i mladi mogu posmatrati u negativnom ili pozitivnom svetlu, gde mlad konotira zdrav, energičan, veseo, lep, zanimljiv. Ipak, ejdžizam je najčešće shvaćen samo u užem smislu, tj. kao diskriminacija starijeg stanovništva. Levi i Banadži (2002) ejdžizam definišu kao promene u osećanjima, stavovima ili ponašanju koja nastaju kao odgovor na poimanje nečijih godina. Montepar i Zibrovic (2002) ejdžizmom smatraju subjektivne i često negativne stavove odraslih ljudi prema starijim osobama. Prvi je pojam ejdžizam uveo i opisao Robert Batler 1975. u svojoj knjizi Zašto preživeti? ${ }^{1}$ ilustrujući društveno dominantno poimanje starenja u Americi, gde se ovaj prirodni proces izjednačava sa siromaštvom, usamljenošću i bolešću - što nije daleko od dominantno negativnog diskurzivnog i društvenog konstruisanja procesa starenja u našoj zemlji. Batler (1975) je ejdžizam definisao kao sistematsku stereotipizaciju i diskriminaciju ljudi samo zato što su stari.

Ejdžizam je, dakle, rasprostranjen fenomen diskurzivne i društvene diskriminacije starosne grupe drugačije od sopstvene, i, pored seksizma i rasizma, predstavlja još jedan način izopštavanja određene društvene kategorije. U poslednje vreme se mnogo više pažnje posvećuje borbi protiv prva dva „-izma" - rasizma i seksizma, kako na društvenom, tako i na diskurzivnom planu - svoj diskurzivni prostor dobijaju rodno osetljivi i politički korektan jezik, a čak se i neke, na prvi pogled šale, smatraju samo suptilno prikrivenim rasizmom/seksizmom i cenzurišu se. Treći "izam", međutim, još uvek nije dobio dovoljno na značaju, što sugeriše u kojoj meri su negativni stavovi prema starijima normalizovani i ukorenjeni u svakodnevnom diskursu, te se ne smatraju problematičnim. Levi i Banadži (2002) primećuju da činjenica da postoji jako malo istraživanja koja se bave ejdžizmom govori u prilog lakoći sa kojom se prihvata ovaj oblik diskriminacije - nasuprot rasizmu, ejdžizam ne izaziva velike društvene reakcije i ne smatra se sramotnim ponašanjem. Interesantno je da je ejdžizam, za razliku od seksizma i rasizma, uvek usmeren ka starosnoj grupi, tj. društvenoj kategoriji kojoj ćemo i sami jednog dana pripadati. Fiske (2010) navodi da su ljudi najviše pristrasni u ocenjivanju spoljašnjih grupa (outgroups), tj. grupa kojima sami ne pripadaju i da su te spoljašnje grupe tipično ocenjene negativnije nego grupa kojoj pripadaju (ingroups). U ovom slučaju, spoljašnju grupu čine stari, koji predstavljaju neku vrstu pretnje našoj društvenoj grupi, verovatno jer nas podsećaju na proces starenja i završetak života. Kajt i Vagner (2002) primećuju da uprkos želji većine ljudi da dugo žive, u društvu u kojem se najviše ceni mladost dok stanovništvo

\footnotetext{
${ }^{1}$ Why survive? Being old in America (1975)
} 
ubrzano stari, negativni stavovi o starenju i starima opstaju. I društvene grupe koje neguju diskriminatorni diskurs prepun ejdžizama takođe prolaze kroz različite životne dobi, pa će nesumnjivo u jednom trenutku i same biti žrtve takvog diskursa. Džendron i Velford (2016) navode da su antiejdž proizvodi dokazi ejdžizma na makronivou, dok se na mikronivou ejdžizam sreće u svakodnevnom jeziku koji predstavlja repertoar suptilnih uvredljivih primedbi o starima i starenju. Ng (2007) primećuje da u društvu koje idealizuje mladost, pridev "star" konotira vrednost kada se odnosi na antikvarni nameštaj ili dobro vino, ali gubi tu vrednost kada se odnosi na muškarce i žene u godinama. Autor (ibid.) navodi i da će stariji ljudi tipično shvatiti kao kompliment iskaze poput "izgledate mlađe/ mladoliko/ mladi".2

Postoje i mišljenja da su ovakvi stavovi prema društvenim grupama različitim od sopstvene urođeni, jer su rezultat jedne automatske kategorizacije. Tako Nelson (2016) smatra da postoje tri osnovne kategorije u koje ljudi smeštaju jedni druge, i to na osnovu tri kriterijuma: rasa, pol i starost. Autor (ibid.) navodi i neophodnost istraživanja ovog procesa primitivne kategorizacije usled njegovog velikog uticaja na društvenu percepciju, formiranje stavova i formiranje i održavanje predrasuda.

Iako automatska kategorizacija ljudi verovatno postoji, tako da prilikom susreta sa osobom automatski percipiramo njen pol, godine i boju kože, ona ne sme biti izgovor za diskriminatorne diskurse i prakse izazvane stereotipima i predrasudama. Moguće je kategorizovati osobu na osnovu ovih dimenzija bez upotrebe diskriminatornog jezika i bez razvijanja negativnih uverenja o njoj na osnovu jedne od ovih dimenzija. U ovom radu fokus će biti na kategorizaciji ljudi na osnovu njihovih godina i analizi pridruženih negativnih atributa koji se automatski povezuju sa ljudima u godinama, tj. na ejdžizmu čija su meta najstariji građani, koji su, u kontekstu celokupne situacije sa pandemijom, i najviše diskriminisani.

\section{Korpus}

Analiza diskursa o najstarijima sprovedena je na kreiranom korpusu koji su činili komentari čitalaca na elektronskim portalima i izjave državnog vrha u periodu od proglašenja vanrednog stanja, 15. marta, do njegovog ukidanja 6. maja 2020. godine. Prilikom kreiranja korpusa pretraženi su brojni elektronski portali koji su prenosili ili vesti o novim merama koje se odnose na starije sugrađane ili obraćanje državnog vrha sa konferencija za štampu. Međutim, nisu svi portali ispunjavali prethodno definisane uslove, od kojih je najvažniji uslov mogućnost ostavljanja komentara ispod vesti i

\footnotetext{
2 "You don't look your age" u originalnom tekstu (Ng, 2007).
} 
postojanje takvih komentara. Drugi važan kriterijum jeste da su ove vesti čitane, odnosno da su portali na kojima se one nalaze posećeni i vidljivi u medijskom prostoru. Zbog toga su komentari čitalaca i izjave državnog vrha preuzeti sa portala Blic, Informer, Alo, Srpski telegraf, Danas.

Komentari koje čitaoci ostavljaju na portalima prikupljeni su, analizirani i interpretirani kao stav društva prema najstarijima, dok su izjave državnog vrha na konferencijama za medije analizirane i interpretirane kao stav države prema najstarijima; nekoliko komentara građana koji su se izjasnili kao penzioneri analizirani su kao stav najstarijih građana. Prilikom analize, korpus je podeljen na potkorpuse, pa su izjave društva, izjave državnog vrha i nekoliko komentara najstarijih građana zasebno analizirani.

\section{Analiza diskursa društva o najstarijima}

Neki od prikupljenih komentara oslikavaju pretežno negativne stavove društva prema starijim sugrađanima i potkrepljuju stereotipe i predrasude o toj starosnoj grupi. Nešto manji broj komentara zalaže se za bolji položaj starih, za normalnije sate za kupovinu i dužu šetnju, tj. ovi komentari ilustruju negativne stavove prema diskriminaciji i ponižavanju starih uvođenjem restriktivnih mera samo za tu kategoriju stanovništva. U analizi koja sledi biće predstavljeni najpre komentari koji neguju predrasude prema jednoj starosnoj grupi, a potom će biti prikazani i komentari koji te česte, implicitne predrasude prepoznaju i odbacuju ih.

\subsection{Negativni stavovi društva o starima i najčešći ejdžizmi}

Prikupljeni komentari razvrstani su prema ejdžizmima koje potkrepljuju. Sledi lista najčešćih ejdžizama u diskursu društva o starima i analiza komentara koji neguju stereotipe i diskurzivno grade negativnu sliku najstarijih.

\section{Stariji su prepredeni, lukavi i neophodno ih je kontrolisati}

- $\quad$ ko će da kontroliše da li se šetaju samo 30 minuta ili duže i ko će da meri da li su dalje od 300 metara od kuće

- $\quad$ A ko će da kontroliše penzionere da li su napolju pola sata ili duže?

- $\quad 65+$ se šetaju i niko ih ne opominje niti kažnjava;

Neki od komentara na portalima preispituju donete mere koje su penzionerima omogućile da izađu iz kuće par dana nedeljno po pola sata kako bi prošetali, i to najviše 
$300 m$ od kuće. Ovi komentari mogu biti shvaćeni kao ismevanje donetih mera i tačno određenog vremena i putanje njihovog kretanja, ali mogu biti interpretirani i kao implikacija da je potrebno da neko kontroliše i meri koliko penzioneri šetaju, jer će oni zasigurno pokušati da prevare sistem i šetaju duže i dalje nego što im je dozvoljeno. Upotrebom glagola kontrolisati, opominjati i kažnjavati stari ljudi se diskurzivno infantilizuju, tj. stavljaju u rang sa neposlušnom decom koja namerno krše sva pravila i ograničenja. Ovakvi komentari jasno oslikavaju ejdžizam star = lukav, nepos/ušan, te opravdavaju stav da je neophodna kontrola, jer se unapred pretpostavlja da najstariji neće ispoštovati donete mere, već će na svoju ruku produžiti šetnju ili otići malo dalje od mesta prebivališta. Ovakav narativ nije ništa novo ukoliko se imaju u vidu prethodno pomenute i gotovo automatski usvojene predrasuda o različitim starosnim grupama.

\section{Stariji ne poštuju mere i neodgovorni su}

- Evo skoro $11 \mathrm{~h}$ a marketi puni starih ljudi;

- Zemunskim kejom ne može da se prođe od penzionera;

- Živa istina. Najneodgovorniji su;

- Penzosi ti se šetaju sve u 16 već 9 dana ima ih više no mladih po ulici, makar u Užicu.

- $\quad$ 9.5\% ide u kupovinu u 4 ujutro. Ostalih 90.5\% ide u kupovinu sa nama ostalima u toku dana.

- O čemu vi pričate ja bre svaki dan srećem penzose po apotekama, prodavnicama itd!!!

Brojni su i komentari u kojima se stariji označavaju kao neodgovorni jer ne poštuju mere. Upotrebom jezičkih sredstava poput marketi puni starih ljudi, ne može da se prođe od penzionera, ostalih 90,5\% ide u kupovinu sa nama ostalima autori ističu masovnost penzionera koji u velikom broju svesno krše mere, dok se iskazima penzosi ti se šetaju sve u 16 već 9 dana, ja bre svaki dan srećem penzose ističe da se to kršenje mera nije dogodilo jedanput, već da penzioneri nonšalantno, svakog dana, "sve u 16", iznova i iznova krše mere - ne ostaju u kućama i ne idu u kupovinu u ranim jutarnjim satima. Superlativom najneodgovorniji direktno se na najstarije sugrađane prebacuje krivica za aktuelno stanje sa pandemijom u našoj zemlji. 


\section{Stariji krše mere i potrebno ih je kazniti}

- Tako da ovi manekeni sa dugim cevima bolje da zađu po šetalištu i pošalju gospodu kućama;

- Gde ti je sad policija ili smo samo jaki na rečima;

- Kažnjavajte njih zbog toga, a ne nas.

Česti su i komentari koji aktivno pozivaju snage reda - policiju i „manekene sa dugim cevima" tj. vojsku - da sprovedu penzionere kućama, da ih opomenu i kazne jer su napolju. Iskazom kažnjavajte njih zbog toga, a ne nas diskurzivno se kreiraju dve grupe - mi i oni - mi koji poštujemo mere i oni koje treba kazniti. Diskurzivnim razlikovanjem naše i njihove grupe, nas poslušnih i njih neposlušnih, nas koji smo u kućama i njih koji se bezobzirno šetaju, jezičkim insistiranjem na različitosti dveju društvenih i starosnih grupa, stvara se plodno tle za stereotipe, predrasude i diskriminaciju.

\section{Stariji su glavni krivci za pandemiju}

- Na šta to liči, zbog takvih će ovo trajati ko zna koliko i imati veće posledice;

- Da li ćemo morati zbog njihove neodgovornosti, nepos/ušnosti da svi trpimo, mi koji moramo da radimo, dodatne mere;

- Dvostruki aršini za disciplinovane i nedisciplinovane. Zato smo i došli dovde!

Stariji se takođe opisuju kao glavni i direktni krivci za trajanje pandemije ( $z b o g$ takvih će ovo trajati ko zna koliko) i za njen intenzitet, tj. aktuelnu epidemiološku situaciju u zemlji (zato smo i došli dovde). Stari su označeni kao grupa zbog koje će radno sposobno stanovništvo trpeti posledice i još jednom su predstavljeni kao osobe sa manjkom odgovornosti prema sebi i drugima - neodgovorni i nepos/ušni jer ne rade ono što im se kaže, a posebno se ističe polarizacija mi (disciplinovani) - oni (nedisciplinovani). Zbog njihovog ponašanja, eksplicitno je rečeno, patićemo mi koji moramo da radimo; eksplicirana i naglašena patnja radno sposobnog stanovništva implicira šta oni misle o drugoj strani - njima: oni ionako samo sede kod kuće.

\section{Stariji su nerazumni}

- Samo još da se penzionerima utuvi u glavu da nemaju potrebe da izlaze napolje; 
- Penzioneri urazumite se $i$ ne izlazite iz kuća!

Ova slika najstarijih koja se diskurzivno gradi dopunjava se i drugim karakteristikama koje su posledice generalizacije i predrasuda, poput onih da su stariji ljudi ograničeni i da ne mogu nešto lako da shvate, da su nerazumni i iracionalni, o čemu svedoči upotreba frazeologizma utuviti u glavu i glagola urazumiti. Ovakvim iskazima stari se ponovo izjednačavaju sa decom, nesposobnom da promisle o mogućim posledicama svojih akcija, tj. stari se ne smatraju odraslim ljudima koji su sposobni da procene situaciju i rizike po sopstveno zdravlje.

\section{Stariji su nesposobni da donose važne odluke}

- Još da zabrane ovim preko 65 godina da glasaju i pun pogodak.

Jedanput se poziva i na dalje oduzimanje prava najstarijima, poput prava glasa. Ovaj komentar podržava vrlo prisutan ejdžizam u našem društvu, a to je da penzioneri glasaju za bilo koga ako im se nešto pokloni ili obeća ili da oni preterano ne razmišljaju za koga će glasati; verovatno je i da ih autor smatra krivcima za trenutnu vlast u zemlji. Istovremeno pozivajući na oduzimanje prava glasa penzionerima, autor upotrebom markera "još" potvrđuje da su i prethodno donete mere diskriminatorne. Ovo je važan primer podržavanja potencijalne nove diskriminacije najstarijih, a ako ovakvi komentari dobijaju medijski prostor, neguju se, šire i dobijaju pristalice, onda se ovakvi diskriminatorni stavovi prihvataju kao normalni, te bi i potencijalne diskriminatorne prakse u pogledu prava glasa bile lakše prihvaćene jer su već normalizovane u diskursu.

\section{Stariji se guraju po prodavnicama i redovima u sred pandemije}

- jer će u suprotnom odmah nagrnuti u Lidlove i ostale Univere da potroše onih $4 k$ što im je prvorođeni respirator poklonio

- Danas penzija oni se skupili ko čopor kod pošte;

- Svudaaaa su. Sad jedan uzeo stolicu i sedi na nju u redu do apoteke, juče LIDL krcat sa njima

- Marketi puni, ne može da se prođe, šetaju se sve u 16

Nisu retki ni komentari gde se penzionerima zameraju naizgled normalne stvari koje ova starosna grupa čini, kao što je podizanje penzije ili čekanje u redu, na koje 
ostatak društva gleda sa gnušanjem, i tu masovnost i nemogućnost da se penzioneri izbegnu izražava pogrdnim poređenjima - skupili se ko čopor, pridevima krcat i pun, prilogom svuda, glagolom nagrnuti. Sve ovo su jezička sredstva kojom se najstariji građani svode na dehumanizovanu, bezličnu masu koja namerno u jeku pandemije preplavi pošte i prodavnice jer nema pametnija posla. Tako dehumanizovanu grupu lako je negativno oceniti, jer individualni razlozi i potrebe pojedinaca nestaju.

\section{Stariji ne umeju da upravljaju sopstvenim novcem, pohlepni su i rasipnici}

- Ne trošite bake i deke puno para valja posle plaćati račune, lekove.... Štedite

- I molba za njih nemojte sve pokupovati ostavite nešto i za nas mlađe.

Pojedini komentari oslikavaju zabrinutost za to kako penzioneri upravljaju svojim novcem, čime se potvrđuje ejdžizam star = nesposoban da upravlja sopstvenim novcem, i ejdžizam star = pohlepan i sebičan; kupuje $\mathrm{i}$ ono što mu ne treba. Imperativima ne trošite bake i deke puno para, štedite, nemojte sve pokupovati daju se saveti starijima u vezi sa novcem i mole se da ne isprazne rafove u prodavnicama - presuponirana informacija je ta da su stariji rasipnici i da svojom penzijom mogu da kupe toliko toga da na kraju ništa ne ostane za druge - što je daleko od stvarne slike i starih i njihovih vrlo često skromnih primanja.

\section{Stariji žele da žive doveka}

- Jel ste se nakupovali? samo vi da ostanete živi 200 godina...pola ih je došlo samo da bi stajali u redu jer su navikli.

Još jedan komentar osvrće se na kupovinu namirnica, i jednu takvu običnu, svakodnevnu radnju zamera najstarijim sugrađanima retoričkim pitanjem Jel ste se nakupovali? Ovakav komentar podržava čest narativ da je penzionerima dosadno, da nemaju čime u životu da se bave, te rade besciljne radnje, poput pukog čekanja u redovima, kao i narativ da penzioneri hoće da žive beskonačno i da se samo bore za to. 


\section{Stariji su se naživeli}

- Pa taj virus nije smrtonosan za zdrave osobe već za stare i već sa zdravstvenim problemima.

Možda je najsuroviji narativ onaj da nije strašno ako najstariji umiru, jer su se već naživeli, uostalom, čemu oni još mogu da se nadaju? Ovakav narativ, kojim društvo procenjuje da li je neko dovoljno živeo ili ne, otkriva stav da ne postoji razlog za brigu ako će od virusa umreti samo stari i samo osobe koje već imaju zdravstvene probleme. Ovaj komentar zapravo počiva na ejdžizmu mladi = zdravi; ne samo da osobe sa zdravstvenim problemima mogu da budu mlade, već i stari imaju pravo da dobiju odgovarajuću negu i da žive onoliko koliko im to priroda dozvoli; rizik umiranja od korone se povećava sa godinama, ali to nikako ne znači da je svejedno da li neko umire ili ne, bez obzira na broj godina, udruženih oboljenja i slično. Narativ da stare treba pustiti da umiru jer su stari i život im je ionako pri kraju - užasan je.

\section{Stariji su privilegovani}

- Nemam ništa protiv penzionera ali delili im maske a moje dete mora da kupuje platnene maska

Zanimljivi su i komentari koji počinju "disklejmerima"3 i osuđuju privilegije koje imaju penzioneri, ali ne i drugi članovi društva. I ovakvi komentari neguju i produbljuju polarizaciju mi - oni, u ovom slučaju moje dete - penzioneri.

\section{Stariji pipaju namirnice u prodavnici i ogovaraju}

- Moja glupa svekrva se pojavila na naša vrata, nenajavljena i nepozvana par sati pre nego što im je zabranjen izlazak iz stana. Samo što me šlog nije strefio. Došla je sa punim kesama namirnica (koje su dobrano ispipane), promenila dva busa, a da ne pominjem da joj dnevno u stan dođe deset kokošaka da se "tetkišu". Izvinite svi fini, obrazovaniji i kulturniji, ali meni je moja svekrva sa tako visoko rizičnim ponašanjem najveća pretnja, pogotovo što je njen sin-moj suprug imunokompromitovan.

\footnotetext{
${ }^{3}$ Izrazi kojima se govornik ograđuje od negativne interpretacije svog iskaza
} 
Ponekad se autori služe i naracijom kako bi uverljivije preneli svoj negativan stav o penzionerima; ovde se ističe najpre njihova nepristojnost leksemama nenajavljena i nepozvana, i njihova ograničenost leksemom glupa. Zatim autorka opisuje gospođu koristeći sve one u društvu ukorenjene predrasude o starima - da vole da pipaju namirnice po marketima, da ne izlaze iz gradskog prevoza i da ogovaraju sa drugim penzionerima. Negativne stavove o starijima konotiraju i upotrebljeni načini imenovanja: kokoške za penzionerke i tetkisati za razgovarati. „Disklejmerom" Izvinite svi fini, obrazovaniji i kulturniji želi se izbeći generalizacija pred ostatak iskaza kojim se svekrva izjednačava sa najvećom pretnjom.

\subsection{Pozitivan stav društva prema starima i prepoznavanje i odbacivanje ejdžizama \\ Međutim, stav društva prema starima nije homogen, pa tako postoje i suprotna gledišta i ljudi koji se ne slažu sa donetim merama, ismevaju njihovu apsurdnost i solidarišu se sa najstarijim sugrađanima. Sledi opis jezičkih sredstava koja su dominantna u nešto drugačijem diskursu društva prema starima.}

1. Ironija kao jezičko sredstvo za izražavanje neslaganja sa donetim merama

- Svima da nam podeli lanac dužine 300 metara za šetnju.

- Nije određeno koliko puta smeju da udahnu vazduh tokom šetnje

- Da li moraju da ponesu štopericu sa sobom?

- Radujte se penzosi, bolji ste od kerova. Oni mogu 200 metara, vi čak 300 !;

- Šetnja, pod uslovom da im još nisu atrofirali i oni mišići koje su imali! Svaka čast Vođo, baš si ih spasao

- Pazi, tri puta nedeljno po pola sata ??? Svaka čast.

Autori ovih komentara stavljaju se na stranu penzionera - autor prvog komentara se čak solidariše sa njima upotrebom opšte zamenice svima, i tražeći lanac za šetnju za sve, zapravo prava najstarije populacije izjednačava sa pravima pasa, koji smeju da idu samo tamo kuda vlasnik želi i koliko on to želi; ako li pas pokuša ići negde drugde, vlasnik ga jednim cimanjem lanca može vratiti. Ovakva metafora oslikava u kojoj meri najstariji građani trpe ponižavanje i ograničavanje slobode kretanja; oni, poput pasa, mogu da idu samo kuda vlast to želi i onoliko koliko ona to 
želi. Sličan je i komentar gde autor ironično primećuje da Nije određeno koliko puta smeju da udahnu vazduh tokom šetnje i komentar Da li moraju da ponesu štopericu sa sobom? Upotreba ironije u ova dva komentara ima za cilj da istakne apsurdnost donetih mera i precizno određenih minuta i metara za šetnju; iako je pasivnom konstrukcijom nije određeno izostavljen agens, jasno je da je vlast ta koja je odredila koliko i kuda najstariji smeju da prošetaju. Narativ vlasti je da je to učinila kako bi ih zaštitila, ali se takvim ograničavanjem kretanja stari diskriminišu i opet tretiraju kao da su deca - nesposobni da procene situaciju i donesu sopstvene odlike o svom zdravlju - da li će i kada izaći iz kuće. Autori komentara prepoznaju taj ejdžizam star = nesposoban da odlučuje $i$ da se zaštiti, i ismevaju ga tako što podsećaju državu da, pošto su stari nesposobni, striktno propiše i broj udisaja i obavezu nošenja štoperice. Komentar koji ironično poziva penzionere da se raduju jer imaju veća prava, tj. čak celih 100 metara više za šetnju od pasa zapravo prenosi negodovanje povodom izjednačavanja prava kućnih ljubimaca i najstarijih građana. Poslednja dva komentara, sa ironičnim čestitkama Svaka čast i Svaka čast, Vođo, baš si ih spasao prenose upravo suprotno značenje - tih pola sata šetnje ne znači mnogo imajući u vidu period koji su najstariji proveli zatvoreni u svojim kućama.

\section{2. (Retorička) pitanja kao jezičko sredstvo negodovanja protiv donetih mera}

- Možda je logičnije bilo da penzioneri imaju izlaz do 23, pošto tada izlaze psi u šetnju, ali ko će svega da se seti??

- Šta je bre ovo ? Dal ima neko ko sa 65 i više ne ume da se čuva ?

- Starije treba zaštititi ali zar ne bi bilo bolje da to bude u okviru od 2 sata da se ne pravi gužva. Zar kućni ljubimci - psi i njihovi u 95\% neodgovorni vlasnici imaju veća prava od naših najstarijih?

- Zar niste mogli uvesti ponedeljak i petak od 6-11 da mogu da izađu i kupe šta im je potrebno? Govorite kad će se kerovi izvoditi, a penzioneri su vam zadnja stvar, moraju i oni izaći iz stana. Virus vlada, svi smo svesni toga, ali ljudi psihički pucaju zatvoreni u 4 zida.

Komentarima koji imaju oblik retoričkih ili pravih pitanja upućenih vlasti autori izražavaju svoje nezadovoljstvo donetim merama i ponovo ukazuju na diskriminaciju najstarijih. Ta pitanja su ili u formi impersonalnih konstrukcija možda je logičnije bilo da... ili u formi direktnih pitanja upućenih odgovornima zar niste mogli... Retorička 
pitanja ko će svega da se seti, da li ima neko ko sa 65 i više ne ume da se čuva i zar kućni ljubimci [...] imaju veća prava od naših najstarijih služe da: 1) istaknu da vlast uopšte ni ne razmišlja o pravima i zdravlju penzionera, zatim 2) da odbace većinski diskurs da stariji ne umeju da se čuvaju, i na kraju 3) da još jednom sugerišu da su i psi dobili više vremena za šetnju od penzionera. Retoričko pitanje Šta je bre ovo? prenosi nevericu i negodovanje povodom mera koje je država propisala.

3. Negativna subjektivna ocena i negativne emocije kao sredstvo za izražavanje nezadovoljstva prema donetim merama

- Zgrožena sam i poražena kao čovek kad čitam ovakve vesti. Živim u inostranstvu gde se država sa dužnim poštovanjem obraća svim svojim građanima...Staviti građane starije od 65 u kućni pritvor ako su zdravi je protivno zdravom razumu i moralu...Imati toliko nepoštovanja prema građanima sopstvene države je za mene neshvatljivo. Tako su se ponasale okupacione snage, sa gnušanjem prema narodu koji su okupirali

- Ponižavajuće je da ovo bude samo tri puta nedeljno;

- Koje ponižavanje penzionera.... oni su stari i trebaju da čekaju u redu u 4 sata ujutru;

- Za šta su se naši borili celoga života??? Za kupovinu od 4-7??? Tuga

- Totalnom zabranom izlaska, gradjani stariji od 65 godina su nepravedno i nepotrebno kaznjeni

- Sramota sta rade tim ljudima....zatvorili ih kao zivotinje a mladi svaki dan prave prvi maj.

Autori ovih komentara iskazuju negativna osećanja prema donetim merama, i to čine koristeći lekseme ponižavanje, sramota, tuga, zatim sintagme zgrožena $i$ poražena kao čovek, nepravedno i nepotrebno kažnjeni. Iz prvog komentara jasna je implikacija da se naša država ne obraća svim svojim građanima sa dužnim poštovanjem, naprotiv, autor ono što država naziva zaštitom starijih građana naziva kućnim pritvorom. Kako bi se dočarao intenzitet nepoštovanja i ponižavanja najstarijih autor koristi i hiperbolu i ratnu metaforu vlasti = okupacione snage, donositi mere = okupirati. Posebno je interesantan poslednji komentar čiji se autor solidariše sa najstarijima, ali na račun mladih - nakon konstatacije da su stari zatvoreni poput životinja, autor komentara pravi kontrast sa mladima koji svaki dan prave prvi maj, 
tj. autor prihvata i održava ejdžizam mladi = neodgovorni, sebični, svaki dan slave u jeku pandemije. Ovaj komentar, iako se načelno bori za prava penzionera, to ne čini tako što krivi državu za donete mere, već imenuje mlade kao glavne krivce za širenje virusa, dok su stari nepravedno zatvoreni.

\section{Analiza diskursa državnog vrha o najstarijima}

Državni vrh se na samom početku nije dao pokolebati; svaki, pa i najmanji poziv da se penzionerima omogući kakva-takva šetnja dočekani su sa prezirom i ispraćeni najmračnijim predviđanjima, ilustrovanim u izjavama koje slede:

- Dragi penzioneri, NE IZLAZITE NAPOLJE!!! Ako pos/ušate takve predloge neće nam biti dovoljno ni Bežanijsko, ni Novo groblje, ni Centralno groblje, ni Lešće... Biće mala da prime sve nas.

Naklonjenost starijim građanima izražena je obraćanjem pridevom dragi i patosom ${ }^{4}$ koji sledi; imperativom ne izlazite napolje izriče se snažna naredba, a protiv izlaska napolje državni vrh koristi argument apokaliptične slike prepunog groblja koje ne može da primi sve mrtve; ovim se kod svih slušaoca, ali naročito penzionera, stvaraju osećanja straha i neizvesnosti koja ih parališu i doprinose njihovom ostanku u kućama. Upotreba ovakvih jezičkih sredstava i kognitivnih slika koje ona izazivaju služi za održavanje kontrole i poslušnosti, za vladanje putem straha i svakako ne pristaju diskursu državnog vrha.

- Nemojte tako da se dodvoravate penzionerima, starijim ljudima. Ljudi, BORITE SE DA NAŠI RODITELJI OSTANU ŽIVI! Penzioneri, molim vas, nemojte da izlazite uopšte. Pa, zamislite da imamo 500.000 penzionerima na ulicama Beograda. Je I' neko razmišlja o tome? Šta je nekome koji to predlaže? Je I' toliko važna vlasti politika? A posle je Vučić zlikovac, jer ne da ljudima da se prošetaju, taj koji ne brine o njihovim kućnim ljubimcima. Samo čekam da neko kaže - hajde da prošetamo papagaje. Ne tražite razlog da neko izađe na ulicu, nego da ostane kod kuće.

\footnotetext{
${ }^{4}$ Patos (pathos) podrazumeva retoričke procese kojima govornik teži da probudi osećanja auditorijuma i tako zadobije njihovo poverenje.
} 
Svaki pokušaj da se skrene pažnja na posledice takvog zaključavanja označen je kao prikupljanje političkih poena i biračkog tela, što predsednik eksplicitno ne odobrava imperativom nemojte tako da se dodvoravate penzionerima, starim ljudima. Zatim imperativom borite se poziva na akciju mlade i stanovništvo srednjih godina, te na njih prebacuje odgovornost očuvanja života najstarijih. To čini iskazom kojim insistira na ozbiljnosti situacije i bliskosti sa narodom i penzionerima upotrebom prisvojne zamenice naši, dok s druge strane preklinje penzionere da nigde ne izlaze. Predsednik potom svoju publiku navodi da zamisli imaginarnu situaciju - pola miliona penzionera na ulicama - i njene negativne posledice, koje ne saopštava eksplicitno, ali su one očigledne - implikacija je da bi došlo do masovnog zaražavanja. Retoričkim pitanjima koja slede potpuno se diskredituje potez opozicije da zahteva da se starijima omogući šetnja $\mathrm{i}$ to tako što se implicira da opozicija ne razmišlja o potencijalno užasnim posledicama jedne takve odluke i da taj koji ovo predlaže (opozicija) ne razmišlja zdravorazumski: Je I' neko razmišlja o tome? Šta je nekome koji to predlaže? Je I' toliko važna vlasti politika? Predsednik potom daje prostor viktimizujućem diskursu, gde podseća javnost na optužbe da je on zlikovac. Apsurdnost zahteva da se penzionerima omogući šetnja predsednik slikovito ilustruje, izjednačavajući razumni zahtev za šetnju najstarijih sa besmislenim razlozima izlaska iz kuće, poput šetanja papagaja. Na kraju eksplicitno zahteva da se prekine sa pronalaženjem razloga za izlazak iz kuće.

- Molim vas, drage penzionere, kao Boga, a ne moram da govorim koliko vas volim... Sve ovo što radimo radimo zbog vas. Nemojte da izlazite iz kuća. Organizovaćemo pomoć za one koji su sami. Ako se dobro organizujemo za deset dana organizovaćemo mlade koji će da vam izvode i kućne ljubimce. Mnoge zemlje organizovanije od nas su strašno poklekle.

- Molim vas da ostanite po svojim domovima, posebno vi u gradovima. Vi ste meta ovog 'napada'. Molim sve nas mlađe, sredovečne i starije od sredovečnih da ne idemo kod starijih, da im ne šaljemo decu, da posećuju deke i bake. Da pustimo deke i bake da budu sami mesec dana, da nam prežive ovo. Znam koliko im je teško bez dece i unuka, ali to je jedini način da prežive. 
Još nekoliko iskaza u kojima predsednik traži od penzionera da ne izlaze iz svojih kuća prepuni su preklinjanja, patosa i iskazivanja beskrajne ljubavi prema bakama $i$ dekama (koja se primećuje, ne mora čak ni biti iskazana). Predsednik ističe ozbiljnost situacije koristeći ratnu metaforu: korona je napad, a penzioneri su meta. Repetitivnom upotrebom glagola organizovati ostavlja utisak pripremljenosti i spremnosti države da na sve načine pomogne najstarijima, a eventualni neuspeh u tome pravda se time što su uređenije države poklekle, te ako mi uspemo, onda je taj uspeh još veći. Još jednom se insistira na bliskosti sa narodom i na jedinstvu upotrebom zamenica nas, nam.

- Ljudi, penzioneri, gube strpljenje i teško im je, ali smo bili uspešni jer smo njihove živote sačuvali. U prethodnom vikendu izašlo da kupuje oko 9,5 odsto penzionera. Najveći deo penzionera razumeo je mere

- Ako budemo morali, u naredna 72 sata donećemo odluku iz ljubavi prema roditeljima, i ne isključujemo mogućnost ako kršenje bude 0,1 do 0,2 odsto da donesemo obavezujuću odluku da sva lica moraju da ostanu u svojim kućama, odnosno dvorištima, ako su na seoskom području. To važi za starija lica. Molim ih jer to radimo za njih. Neće stradati naša deca, već naši roditelji. Zato ih molim da ne izlaze iz kuće

Kada su u pitanju uvedene mere za kupovinu koje nalažu da stari ljudi moraju da ustaju u četiri ujutru ne bi li otišli do prodavnice, jer često nemaju nikog da im donese namirnice i pomogne, predsednik države to vidi kao uspeh. Poslednja dva komentara ilustruju diskurs kojim se zaključavanje najstarijih pravda upravo ljubavlju prema njima i kojim se insistira na tome da će stariji umreti ako ne postupe kako država želi; neguje se diskurs da je kršenje njihovih prava samo za njihovo dobro, jer je jasno da stariji ljudi ne mogu sami da razaznaju šta je za njih dobro, a šta ne, već to umesto njih mora odlučiti država koja je u ovim komentarima predstavljena kao stroga i odlučna, te vlast neće prezati od uvođenja težih mera čak i ako kršenje postojećih bude minimalno. Upotrebom prvog lica množine predsednik preuzima delimičnu odgovornost za donošenje restriktivnih odluka, ali se uslovnom rečenicom ako budemo morali i konstrukcijom donećemo odluku umesto jasnijeg odlučićemo ipak od te odluke ograđuje. Uz još nekoliko molbi starijima da ne izlaze iz domova, 
predsednik neprestano podseća na jedinstvo sa narodom, naglašavanjem da su u pitanju naša deca i naši roditelji.

\section{Analiza diskursa najstarijih o merama, diskursu društva i diskursu države \\ Prilikom kreiranja korpusa, u sekciji komentari na portalima, pronađeno je i nekoliko komentara penzionera (ili barem autora koji se predstavljaju kao penzioneri), u kojima oni iznose svoje viđenje stvari.}

- Gospodo, ja kao penzioner sam sigurniji na ulici, parku, šumi, šetnji nego kod kuće. Uostalom otkuda vam ideja da penzioneri šire virus i da se ne čuvaju. Pustili ste našu decu da rade u firmama gde ima hiljade zaposlenih bez ikakve zaštite i zaštitnih sredstava. Mislite li da mladi ne mogu dobiti virus ili ste pili možda bunike. Kada saznamo da neko ima virus već je kasno. Šta vi sa ovom zabranom uopšte hoćete da postignete. Stavljate nas kao ovce u tor za klanje.

Autor ovog komentara prepoznaje rasprostranjene ejdžizme upućene upravo društvenoj kategoriji kojoj pripada i odbacuje ih - pitanjem otkuda vam ideja da penzioneri šire virus i da se ne čuvaju implicira da se penzioneri ne čuvaju ništa manje nego drugi članovi društva. Iskazom kojim autor tvrdi da je sigurniji van svoje kuće istovremeno ruši ejdžizam da stari ne umeju da procene gde su bezbedniji - autor jasno stavlja do znanja da ume da proceni rizik za sopstveno zdravlje, što je u suprotnosti sa viđenjem društva i države, koja starije smatra nesposobnim da sami odlučuju. Ovaj iskaz iznosi i poznat društveni problem, koji ni država ni društvo ne žele da vide, a to je problem življenja više generacija pod jednim krovom, tako da stari ni da hoće, ne mogu da se izoluju. Autor otvoreno kritikuje način na koji vlast vodi pandemiju, odnosno to što država ne želi da vide da stariji vrlo lako mogu dobiti virus od mlađih sa kojima žive, tj. što je mlade pustila da rade bez zaštitne opreme. U komentaru je slikovito prikazano ignorisanje činjenice od strane vlasti da se i mladi mogu zaraziti virusom i preneti ga starijima - frazeologizmom piti bunike. Ni autoru komentara, koji se predstavlja kao penzioner, nisu jasne mere kojima ih država štiti : Šta vi sa ovom zabranom uopšte hoćete da postignete. Iskazom Stavljate nas kao ovce $u$ tor za klanje jasno se iskazuju negativna osećanja prema zaključavanju u kuće i ono se poredi sa praksama koje trpe životinje; ovaj iskaz predstavlja i način na koji penzioneri vide svoj položaj u uslovima pandemije - verovatno je da u uslovima u 
kojima više generacija živi sa „bakama i dekama” pod istim krovom, zaključavanje tih istih ljudi u kuće je daleko od njihovog spasa i borbe za njihovo zdravlje, već je upravo suprotno, osuđivanje na dvadesetčetvoročasovni boravak sa potencijalnim prenosiocima virusa, samim tim i na zaražavanje i neizvesnu borbu sa bolešću.

- Moram u dom zdravlja, moram u banku a pošto imam više od 65 ja sam u zarobljeništvu...osećam se jadno i prevaren...čini mi se da je to sve zato što ovi nespsobnjakovići nisu u stanju ni masku da mi obezbede a torade se, kobojagi zato što me vole.

Pojedini penzioneri skreću pažnju na probleme sa kojima se suočavaju, a koji su, opet, nevidljivi u diskursu države i društva, te kao da ne postoje - pripadnici ove društvene grupe neretko su sami i sami moraju obavljati svakodnevne poslove, a mere ih u tome sprečavaju. Autor subjektivno ocenjuje situaciju u kojoj se nalazi koristeći ratnu metaforu - ja sam u zarobljeništvu i lekseme jadno i prevaren. Odbacuje navode vlasti da će obezbediti maske za najstarije nazivajući predstavnike vlasti nesposobnjakovićima. Autor prepoznaje patos u diskursu državnog vrha, i jezički pokazuje da na njega ne naseda u poslednjom delu iskaza: torade se, kobajagi zato što me vole.

- Starija sam osoba. Ionako teško hodam a cirkulacija slaba, kao i kod svih starijih ljudi, i dok nije bilo policijskog časa, moja šetnja je morala trajati bar jedan sat da bi noge "proradile". Otkako sam stalno u stanu, hodam još teže jer me od sedenja i od nekretanja na svežem vazduhu sve više bole kukovi $i$ kičma, teško se podižem iz sedećeg ili ležećeg položaja. To mi se ne događa kad svakodnevno šetam napolju, obično u obližnjem parku. Preskočim li jedan dan, noge mi već "štrajkuju", a to je zbog neodržavanja kontinuiteta. Pola sata tri puta nedeljno je premalo za nas starije.

U još jednom komentaru ističu se zdravstveni problemi koje stari imaju, i zbog kojih moraju da šetaju redovno, što im je potpuno uskraćeno - to su problemi starih koje država ne želi da vidi. Uz opis problema i generalizacije da svi stari ljudi imaju slabu cirkulaciju i probleme sa hodom, autor objašnjava i da mu se zdravstveno stanje pogoršava otkad ne izlazi napolje, i zaključuje da je vreme koje je država izdvojila za šetnju najstarijih nedovoljno: pola sata tri puta nedeljno je premalo za nas starije. 
- Nemoj vise da brinete o nama jer ste delom pokazali da vredimo manje od svake svakog gradskog kera. Ovo je takvo ponizavanje i krsenje Ustava i svih medunarodnih konvencija da to Evropa dozivela nije.Pitam se gde su penzionerska udrzenja da stanu u zastitu gde he Krkobatic a da nisu izbori pa sto bi se sada secali svog zatvorenog clanstva. Ptedlazem drugu Krkobabicu da nam kupi po 1 zutu zvezdu ionako smo ko Jevreji u getu. IMACETE I VI SVI 65+PA IMAJTE Ovakve PENZIONERSKE DANE. Glasove dobiti necete dobiti od vecine $65+$

Autor ovog komentara poziva vlast da više ne brine o njima, i ukazuje da ono što vlast naziva brigom za starije nije ništa drugo do ponižavanje i kršenje Ustava $i$ svih međunarodnih konvencija. Potom poziva na akciju i udruženja i političare da reaguju i zaštite prava najstarijih. Autor sebe i druge stare zaključane u kućama vidi kroz metaforu holokausta: Predlažem drugu Krkobabiću da nam kupi po 1 žutu zvezdu ionako smo ko Jevreji u getu. Na kraju iskazuje i neku vrstu pretnje upućene odgovornima za ovakvo izopštavanje starih, najpre podsetnikom da će i vlast jednog dana ostariti, a potom i pretnjom da su izgubili biračko telo: IMAĆETE I VI SVI 65+PA IMAJTE Ovakve PENZIONERSKE DANE. Glasove dobiti nećete od vecine 65+.

- Čime je on to nama izašao u susret, dozvolom da se prošetamo 300m a ukinuo nam pravo na slobodu kretanja? Ni u jednoj zemlji nije ukinuto pravo samo jednoj kategoriji stanovništva. Nismo mi ni maloletni ni maloumni, da drzava treba da određuje da li ću napuštati kuću ili ne.

Autor komentara uviđa da nemaju na čemu da budu zahvalni vlasti - kretanje je Ustavom garantovano pravo, a pola sata šetnje ne može zameniti oduzetu slobodu kretanja: čime je on to nama izašao u susret, dozvolom da se prošetamo $300 m$ a ukinuo nam pravo na slobodu kretanja? Koristeći argument analogije Ni u jednoj zemlji nije ukinuto pravo samo jednoj kategoriji stanovništva autor implicira da nema razloga ni da se kod nas to čini. Na kraju poriče implicitni ejdžizam u diskursu državnog vrha - stav da stari ne mogu sami donositi odluke o svom zdravlju - i ruši ukorenjen ejdžizam da su stari poput dece, te da o njima mora brinuti čak i država: Nismo mi ni maloletni ni maloumni, da država treba da određuje da li ću napuštati kuću ili ne. 


\section{Zaključna razmatranja}

Na osnovu analiziranog diskursa društva o starima, može se zaključiti da su u našem društvu ukorenjeni raznovrsni ejdžizmi i da oni upravo zahvaljujući ovakvom diskursu opstaju i jačaju. Stariji su u većini slučajeva označeni kao krajnje neposlušni i bezobzirni prema drugima; zamera im se jer ne poštuju mere, jer šetaju i idu u prodavnicu preko dana, čekaju u redu za poštu ili prodavnicu, koriste gradski prevoz, druže se, biraju namirnice. Društvo neguje ovakve i slične stereotipe i ne teži da razume situaciju u kojoj se najstariji nalaze. Ejdžizmi su u diskursu društva izraženi različitim jezičkim sredstvima - uvredljivim imenovanjima (kokoške, tetkisati), hiperbolom i superlativima (meni je moja svekrva najveća pretnja, najneodgovorniji su), brojnim atributima sa negativnom konotacijom (nenajavljena, nepozvana, glupa, neodgovorni, nepos/ušni, nerazumni, nedisciplinovani), glagolima, pridevima i imenicama sa semom [+masovnost] (puni, krcati, čopor, nagrnuti). U diskursu društva se neretko insistira i na različitosti njih (nedisciplinovnih i privilegovanih) i nas (disciplinovanog radno sposobnog stanovništva). Nasuprot ovom diskursu, postoji i drugačiji diskurs o starima, u čijem je fokusu nelogičnost donetih mera i saosećanje sa najstarijima - jezička sredstva upotrebljena da prenesu nezadovoljstvo su ironija, retorička pitanja i iznošenje negativnog subjektivnog stava: zgrožena sam, poražena; ili subjektivne ocene situacije: nepravedno, nepotrebno, ponižavanje. Državni vrh se u svom diskursu najčešće služi patosom koji treba da ima persuazivnu ulogu - važno je ubediti penzionere u ljubav države prema njima i da su diskriminatorne mere donete upravo iz te brige i ljubavi. Osim patosa, u diskursu državnog vrha prisutne su i ratne metafore, retorička pitanja radi diskreditovanja zahteva opozicije, jezička sredstva koja signaliziraju bliskost i jedinstvo sa narodom (naša deca, naši roditelji, da nam prežive ovo). Dominantni deo diskursa i državnog vrha i društva jeste diskurs kojim se stari ljudi infantilizuju, tj. tretiraju kao da su potpuno bespomoćni. Diskurs starijih građana uglavnom se svodi na prepoznavanje implicitnih i široko rasprostranjenih ejdžizama, kao i državnog patosa i infantilizujućeg diskursa, i odbacivanje tako stvorene diskurzivne slike o sopstvenoj starosnoj grupi.

Društvo u svom diskursu neguje različite ejdžizme, a u korpusu su pronađeni komentari koji potkrepljuju sledeće ejdžizme: stariji krše mere, neodgovorni su, neophodno ih je kontrolisati i kazniti; stariji su glavni krivci za epidemiološku situaciju u zemlji, nerazumni su i nesposobni da samostalno donose odluke; oni žele da žive zauvek, privilegovani su. Stariji su označeni i kao pohlepni i sebični, kao osobe koje se u sred pandemije guraju po prodavnicama i redovima, i kao grupa stanovništva koja 
je dovoljno živela, te nije strašno i ako umiru od korone. U korenu ovakvih ejdžizama su pre svega predrasude i stereotipi jedne društvene grupe o drugoj, dok je stvarnost često potpuno drugačija.

Najpre, važno je naglasiti da postoje penzioneri koji nemaju na koga da se oslone, koji nemaju mlađe ukućane koji će im pomoći i otići umesto njih u prodavnicu, poštu i slično, te odlaze sami, jer nemaju drugu opciju. Drugi pak žive sa mlađim generacijama pod istim krovom, gde im njihova deca mogu preneti virus sa radnog mesta, a njihovi unuci sa fakulteta i raznih druženja, te stariji izlaze napolje i šetaju, jer se tada osećaju manje ugroženim. Stariji ljudi često ne mogu da se zaštite od virusa onako kako društvo i država zamišljaju. I kod prvih, koji možda žive sami, i kod drugih, gde nekoliko generacija živi zajedno, postoje zdravstveni problemi, koji zahtevaju svakodnevnu šetnju i kretanje, a tome društvo i država ne pridaju gotovo nikakav značaj. Zaključavanjem u domove država tobože štiti penzionere od korona virusa (i to samo one koji zaista imaju gde da se izoluju), istovremeno ih izlažući riziku pogoršavanja cirkulacije i razvoja drugih tegoba usled nekretanja, kao i depresiji i drugim pretnjama po mentalno zdravlje. Pošto stav javnog mnjenja nije homogen, postoje i pripadnici društva koji tvrde da se radi o kršenju osnovnih ljudskih prava i saosećaju sa najstarijima, ističući da psi imaju prava na dužu šetnju od penzionera i da je kupovina u noćnim satima maltretiranje i ponižavanje najstarijih.

Društvo duboko neguje $\mathrm{i}$ ejdžizam star = nesposoban da upravlja sopstvenim novcem, pa se pojedinci tobože brinu da stari ne potroše svu penziju pa da posle nemaju za lekove ili da ne nakupuju previše toga pa da mlađima ništa ne ostane. Stvarnost je drugačija - i uz podeljenu pomoć države penzionerima, penzije koje prima veliki deo penzionera su minimalne i jedva se sa tim novcem mogu kupiti neophodne stvari, tako da je diskurs o bahatosti i rasipništvu penzionera - daleko od istine.

Državni vrh, pod velom patosa i neizrecive ljubavi prema našim bakama $i$ dekama, oduzima slobodu kretanja najstarijima i predstavlja je kao spasonosnu meru koja će sačuvati njihove živote. I u diskursu države i u diskursu društva, stari su predstavljeni kao nerazumni, iracionalni, nesposobni da procene rizik po sopstveno zdravlje i na osnovu toga donesu odluke, već je najbolje da država sve odluči za njih i da donosi mere za njihovo dobro, što možda najbolje oslikava komentar u kojem se država poziva da nam svima dâ lance od $300 \mathrm{~m}$. Ne samo da potpunu kontrolu i zaključavanje opravdava spasavanjem života, država, zaslepljena diskursom blagostanja i bogatstva, ne vidi sve gore pomenute socio-ekonomske i zdravstvene probleme najstarijih građana, već smatra da će diskursom prepunim patosa ubediti i 
penzionere i društvo da država najbolje zna šta je dobro za koju starosnu grupu i da je u redu da upravlja našim životima kako želi.

Najzad, ponovićemo da su ejdžizmi koje pronalazimo u korpusu zasnovani na predrasudama, negativnim stavovima i generalizaciji, i da se oni ne smeju prihvatati kao prirodni stav prema starima i a priori se usvajati, već se konstatno moraju preispitivati i odbacivati, jer normalizacija diskriminacije u diskursu vodi normalizaciji diskriminatornih društvenih praksi. Naime, nasuprot većinskom diskursu, stari ne mogu da se zaštite onako kako mi zamišljamo usled različitih socio-ekonomskih faktora - niti svi imaju gde da se izoluju, niti imaju mlađe na koje mogu da se oslone. Stari nisu nerazumni, iracionalni i bahati, mogu da donose odluke o sopstvenom zdravlju, izlasku u šetnju i odlasku u prodavnicu, i svaki poziv da ih vojska vrati nazad u kuće ili policija kazni proizilazi iz nerazumevanja problema društvene grupe drugačije od sopstvene. Najstariji sugrađani nemaju astronomske penzije, ne mogu da pokupuju ceo market i umeju da upravljaju skromnim sredstvima kojima raspolažu. Nisu dokoni, ne čekaju u redu samo da bi čekali jer su navikli; ako idu da podignu penziju čim je dobiju, to je verovatno zato što im je od prethodne ostalo jako malo ili nimalo. Najstariji biraju namirnice isto koliko i ostali građani, koriste gradski prevoz kao i svi ostali, i imaju prijatelje, što su normalne stvari za sve starosne grupe. Najzad, treba biti vrlo oprezan sa diskursom da je u redu da najstariji umiru; čovek od 70 godina može doživeti stotu, nije na nama da odlučujemo kada je vreme da neko ode. Ne samo da je ovaj diskurs krajnje sebičan, on je i surov.

Celokupno društvo ne sme negovati diskriminatorne diskurse i prihvatati dominantni državni diskurs i diskurzivno predstavljanje najstarijih kao nesposobnih za bilo šta; moramo se pitati kakva je društvena realnost određenih diskursa; da li je ono što država diskurzivno predstavlja kao spas i zaštitu zaista to u praksi, ili je diskurs samo paravan za diskriminatorne prakse i ograničavanja prava određenih društvenih grupa. Jedino tako se mogu prevazići ejdžizmi, stereotipi, predrasude i generalizacije u diskursu i popraviti pozicija najstarijih u društvu, koji su u ovoj pandemiji dovedeni na marginu društva.

Zaključak valja ostaviti možda najupečatljivijem komentaru u ovom korpusu koji dolazi upravo od predstavnika najstarije društvene grupe, a to je iskaz kojim se ruši rašireni diskurs o starima kao nesposobnim za bilo šta, ali se može proširiti i na druge društvene grupe, kao poziv na razmišljanje o pravima svih ljudi na samostalno odlučivanje i upravljanje sopstvenim životom: Nismo mi ni maloletni ni maloumni,

\section{da država treba da određuje da li ću napuštati kuću ili ne.}




\section{Literatura}

Butler, R. N. (1975). Why survive?: Being old in America. New York: Harper \& Row.

Bytheway, B. (1995). Ageism. Open University Press, Buckingham, 142 pp.

Fiske S. T. (2010). Social beings: Core motives in social psychology (2nd ed.). Hoboken, NJ: Wiley.

Gendron, T.L., Welleford, E.A., Inker, J., White, J.T. (2016). The Language of Ageism: Why We Need to Use Words Carefully. In The Gerontologist, Volume 56, Issue 6, 1 December 2016, Pages 997-1006, https://doi.org/10.1093/geront/gnv066 Greenberg, J., Schimel, J. \& Martens, A. (2002). Ageism: Denying the Face of the Future. In T. D. Nelson (Ed.) Ageism, Stereotyping and Prejudice against Older Persons (p. 27-49). The MIT Press.

Kite, M.E. \& Wagner, L.S. (2002). Attitudes toward older adults. In T. D. Nelson (Ed.) Ageism, Stereotyping and Prejudice against Older Persons (p. 129-163). The MIT Press.

Levy, B.R. \& Banaji, M.R. (2002). Implicit ageism. In T.D. Nelson (Ed.) Ageism, Stereotyping and Prejudice against Older Persons (p. 49-77). The MIT Press.

Montepare, J.M. \& Zebrowitz, L.A. (2002). A Social-Developmental view of ageism. In T. D. Nelson (Ed.) Ageism, Stereotyping and Prejudice against Older Persons ( $p$. 77-129). The MIT Press.

Nelson, T. D. (2016). Ageism. In T. D. Nelson (Ed.), Handbook of prejudice, stereotyping, and discrimination (p. 337-353). Psychology Press.

$\mathrm{Ng}$, S. H. (2007). Language-based discrimination blatant and subtle forms. Journal of Language and Social Psychology, 26, 106-122. doi: $10.1177 / 0261927 \times 07300074$

Van Dijk, T. A. (1993). Principles of Critical Discourse Analysis. Discourse \& Society. 1993;4(2):249-283. doi:10.1177/0957926593004002006 


\section{Summary}

\section{AGEISM IN THE DISCOURSE ON THE ELDERLY DURING THE CORONA VIRUS PANDEMICS IN SERBIA}

As the older citizens were presented as the most vulnerable at the start of the pandemic, they suffered the most severe measures in the fight against the virus - they were locked in their homes, initially without the possibility to go out, then with minimal walking time; they were allowed to go to supermarkets between 4 and 7 am: they were humiliated and discriminated against. Such discriminatory practices against older citizens in the dominant discourse of the President of the State are presented as protection and true love for "grandparents". The aim of this article is to see how the elderly are represented in mainstream discourse and what discriminatory practices lie behind the apparent concern and love for retirees. The objective is also to identify the linguistic means by which ageism manifests itself in discourse, to explain the discursive construction of the concept of aging, and to determine what are the main ageisms that persist in Serbian society.

The ageisms found in the corpus of citizens' comments on various news reports that deal with Covid and of the President of Serbia's remarks during press conferences show that several ageisms are dominant in the discourse of Serbian society: the elderly do not respect the antiepidemic measures and are irresponsible; the elderly are the main culprits of the pandemic; the elderly are unreasonable and unable to make important decisions; the elderly do not know how to manage their own money; they are selfish and want to live forever; the elderly are privileged; the elderly have lived long enough. Ageisms are expressed in the discourse of society by various linguistic means: insulting names, hyperboles and superlatives, attributes with negative connotations. Society discourse often emphasizes the difference between them (undisciplined and privileged) and us (disciplined). The President of the state usually uses pathos in his discourse in order to convince retirees of the state's love for them and assure them that discriminatory measures have only been taken for their own sake. Besides the pathos, the speech of the leaders of the state also includes warlike metaphors, rhetorical questions, and other linguistic means which signal the proximity and the unity with the people. The discourses of the state and the society treat the elderly as if they are completely helpless. The discourse of the elderly mainly aims to recognize implicit and widespread ageisms, as well as pathos and infantilizing discourse, and to reject the discursive image of the elderly created by society and the state.

By reproducing this discriminatory discourse full of ageisms, we normalize discriminatory actions, so this discourse should be questioned and rejected, instead of being accepted as a normal discursive representation of the elderly. Society should not cultivate discriminatory discourses; we have to ask ourselves what is the social reality of certain discourses and determine whether the specific discourse is only a cover for discriminatory practices and restrictions on the rights of certain social groups.

Keywords: critical discourse analysis, ageism, discrimination, the elderly, corpus, discriminatory practices, discriminatory discourse, coronavirus pandemic 